\title{
Loss To Follow Up Pada Odha Yang Menerima Terapi Antiretroviral Di Kecamatan Ujung Bulu Kabupaten Bulukumba
}

\author{
Haerati $^{*}$, Suriah ${ }^{2}$, Fatmah Afrianty Gobel ${ }^{3}$ \\ 1*. STIKES Panrita Husada Bulukumba, Jln Pendidikan Taccorong, Kabupaten Bulukumba, Indonesia, 92561 \\ 2. STIKES Panrita Husada Bulukumba, Jln Pendidikan Taccorong, Kabupaten Bulukumba, Indonesia, 92561 \\ 3. STIKES Panrita Husada Bulukumba, Jln Pendidikan Taccorong, Kabupaten Bulukumba, Indonesia, 92561
}

e-mail: ratihalfayed76@gmail.com/081242520330

(Received: 16-03-2019; Reviewed: 12-04-2019; Accepted: 20-04-2019)

\begin{abstract}
The percentage of loss to follow up (LTFU) at the first one year of ARV therapy becomes the success indicator of this therapy. ODHA experiencing LTFU can cause treatment termination, medicine toxicity, treatment failure of disobedient, and medicine resistance. This research is aimed to know the risk and give description about clinical and behavioural determinant of loss to follow up on ODHA receiving ARV therapy at Public Health Center of Caile Bulukumba.This research employs design Kualitatif method case studi. The population of this research is all ODHA receiving ARV therapy at Public Health Center ofCaile Year 2017. The sample of this research is LTFU 3 people. The informants are 11 people from doctor, counsellor, PMO and ODHA LTFU.The result shows the proportion The LTFU informant did not believe the ARV medication because it had no benefit for their body condition and it was not in the form of commitment in every body to drink medicine for the entire life. ODHA decided to stop medication because they could not retain the side effect and they felt bored in having ARV medication. The LTFU ODHA received social support from employer and from PMO was in the form of emotional, esteem, and informational support. However, there is no support from the family because they were afraid of stigma and discrimination.
\end{abstract}

Keywords : Loss to follow up, antiretroviral therapy

\begin{abstract}
Abstrak
Persentase loss to follow up (LTFU) pada satu tahun pertama terapi ARV menjadi indikasi keberhasilan terapi ARV. ODHA yang mengalami LTFU dapat mengakibatkan penghentian pengobatan, toksisitas obat, kegagalan pengobatan karena ketidakpatuhan, dan resistensi obat. Penelitian ini bertujuan untuk mengetahui kapan, mengapa, bagaimana dan apa rencana selanjutnya ODHA loss to follow up yang menerima terapi ARV. Penelitian ini menggunakan methode kualitatif dengan rancangan studi kasus. Populasi penelitian ini adalah ODHA yang menerima terapi ARV lalu loss to follow up di Kecamatan Ujung Bulu Kabupaten Bulukumba. Sampel penelitian yaitu tiga orang LTFU. Informan berjumlah 11 orang berasal dari dokter, Petugas penanganan HIV dan AIDS, PMO (Keluarga) dan ODHA LTFU.Hasil penelitian menunjukkan.Informan yang berasal dari LTFU memiliki pengetahuan yang kurang tentang HIV dan AIDS serta pengobatan antiretroviral. Informan yang LTFU tidak percaya dengan pengobatan ARV karena merasa tidak memberikan manfaat bagi kondisi tubuhnya dan tidak terbentuk komitmen dalam diri untuk minum obat seumur hidup. ODHA memutuskan pengobatan karena tidak sanggup menahan efek samping dan adanya kejenuhan dalam menjalani pengobatan ARV. ODHA yang LTFU mendapatkan dukungan sosial dari petugas dan LSM serta PMO berupa dukungan emosional, penghargaan dan informasional. Namun, tidak banyak mendapat dukungan dari keluarga karena takut akan adanya stigma dan diskriminasi.
\end{abstract}

Kata Kunci : Loss to follow up, Antiretroviral 


\section{Pendahuluan}

Salah satu aspek kesehatan pada akhir abad ke-20 yang merupakan bencana bagi manusia adalah munculnya penyakit yang disebabkan oleh suatu virus yaitu HIV (Human Immunodefeciency Virus) yang dapat menyebabkan AIDS (Aquarired Immunodefeciency Syndrom). AIDS (Aquarired Immunodefeciency Syndrom) adalah sekumpulan gejala penyakit yang timbul karena turunnya kekebalan tubuh yang disebabkan oleh infeksi HIV, akibat menurunnya kekebalan tubuh maka orang tersebut sangat mudah terserang berbagai penyakit (infeksi oportunistik) yang sering berakibat fatal, pengidap HIV memerlukan pengobatan antiretroviral (ARV) untuk menurunkan jumlah virus HIV dalam tubuh agar tidak masuk kedalam stadium AIDS, sedangkan pengidap AIDS memerlukan pengobatan ARV untuk mencegah terjadinya infeksi oportunistik dengan berbagai komplikasinya (Hardiansyah, dkk 2014).

Kasus HIV dan AIDS di Indonesia cenderung mengalami peningkatan yang terus menerus, hingga tahun 2015 mencapai 184.929 orang dan kasus AIDS mencapai 68.197 orang. Jumlah kasus AIDS terbanyak pada laki-laki (54\%), faktor risiko heteroseksual $(64,5 \%)$ dan golongan umur terbanyak pada 20-29 tahun (32\%). Angka kematian (CFR) AIDS menurun dari 1,22\% pada tahun 2014 menjadi 0,67\% pada tahun 2015 (Ditjen PP \& PL Kemenkes RI, 2015).

Sulawesi Selatan termasuk Provinsi yang memiliki penularan HIV dan AIDS tinggi. Sampai September 2014 menempati peringkat ke-8. Penderita HIV dan AIDS di Sulawesi Selatan jumlah kumulatif sejak tahun 2005 sebanyak 5.159 Orang, Data yang bersumber dari Dinas Kesehatan terhitung dari Juni 2015 hingga sekarang tercatat 9.871 orang. Dimana kasus ini sejak tahun 2013 ada 9.871 kasus dan sebanyak 6.233 penderita AIDS dan 3.638 HIV menurut dari jenis kelamin penderita didominasi oleh laki-laki.

Dari 23 Kabupaten/Kota di Sulawesi Selatan, Kabupaten Bulukumba termasuk 21 daerah provinsi yang telah mengeluarkan Perda AIDS yang dituangkan dalam Perda No. 5 tahun 2008 tentang penanggulangan HIV dan AIDS, yang didalamnya mengatur penyampaian informasi, komunikasi, dan edukasi pada masyarakat tentang HIV dan AIDS, serta melaksanakan pemeriksaan tes HIV dan AIDS terhadap kelompok rawan dan beresiko tinggi, termasuk didalamnya wanita pekerja seksual (WPS) dan Waria (Kemenkes, 2012).

Kabupaten Bulukumba merupakan Kabupaten tertinggi ketiga setelah Makassar dan Pare-pare pada tahun 2012 dengan jumlah penderita HIV dan AIDS sebanyak 107 orang dan pada bulan Maret 2014 bertambah menjadi 113 orang. Jumlah faktor risiko HIV dan AIDS di Bulukumba, yaitu IDU 51 kasus, melalui hubungan seks 29 kasus dan perinatal 3 kasus. Jumlah kumulatif sejak 2006 kematian akibat HIV dan AIDS sebanyak 26 orang (Kemenkes, 2014).

\section{Metode}

Penelitian ini mengunakan penelitian kualitatif dengan metode studi kasus dengan maksud untuk mengetahui kapan, mengapa, bagaimana dan apa rencana selanjutnya ODHA loss to follow up yang menerima terapi ARV.Penelitian ini dilaksanakan di wilayah kerja Kecamatan Ujung Bulu Kabupaten Bulukumba Penelitian dilakukan bulan Juli sampai Agustus 2017.Adapun yang menjadi populasi dalam penelitian ini adalah 13 orang yaitu informan biasa tiga orang dan informan kunci sepuluh orang. Sumber data primer dalam penelitian ini adalah informan, yakni berupa hasil wawancara mendalam, hasil observasi, dan hasil dokumentasi dengan orang-orang tertentu yang dapat memberikan informasi atau keterangan dari data yang dibutuhkan serta catatan yang berisikan gambaran (deskriptif) tentang informasi baik itu tentang ODHA yang menerima terapi ARV. Data yang didapatkan dengan mengkaji dokumen yang berhubungan dengan objek penelitian, baik berupa catatan medik, hasil pemeriksaan, maupun sumber tertulis lainnya yang masih berhubungan dengan objek penelitian.

\section{Hasil Penelitian}

\section{Pengetahuan}

Berdasarkan hasil wawancara mendalam pada informan yang loss to follow up menyatakan bahwa HIV dan AIDS merupakan virus yang berbahaya, mematikan dan tidak tahu sampai kapan akan hilang. Penularanya melalui hubungan seksual, jarum suntik dan transfusi darah.Pencegahannya dengan menjauhi seks bebas, menggunakan kondom dan tidak narkoba.

"Penyakit yang mematikan.Penyakit menular yang melalui seks kelamin, yang melalui darah, ibu menyusui. Pakai ki kondom saat berhubungan seksual biar nda tertularki do". (AM, 45 tahun, LTFU)

"Semacam virus yang kita tidak tahu sampai kapan Penularannya do..emmm melalui hubungan seksual, jarum suntik, ee dengan apa itu deh, lupaka bu. Tapi yang cepat ketularan itu hubungan seksual.Pakai kondom saat berhubungan seksual biar tidak tertularki”.(MI, 22 tahun, LTFU)

"Penyakit yang berbahaya. Cara penularannya melalui jarum suntik, seks bebas, pakai jarum suntik kayak narkoba do, transfusi darah itu ji saya tahu bu. Pencegahannya jauhi seks bebas atau kalau mauki harus pake kondom bu,". (HS, 32 tahun, LTFU).

"Penyakit yang mematikan karena obatnya belum ditemukan yang pasdan harus diminum seumur hidup. ckckckckckkk. Mete tongekka iya. Ini penyakit,menularnya melalui hubungan badan, ada yang melalui darah emm 
ganti-ganti jarum suntik, istri hamil terus menular ke anaknya juga karna menyusui. Nah supaya tidak menularkan ke orang ya janganki baku pake-pake, Pakai ki kondom saat berhubungan seksual biar nda tertular sama orang" (AT, 33 tahun, LTFU yang meninggal saat penelitian)

"Penyakit yang menular makanya haruski minum obat seumur hidup. Menularnya melalui seksual, ada yang melalui jarum suntik,. Nah supaya tidak menularkan ke orang yaaa setia pada pasangan, Pakai ki kondom saat berhubungan seksual biar aman. (ED, 29 tahun, LTFU yang meninggal saat penelitian)

"Penyakit yang mematikan...Inimi penyakitku yang bawaka mati,menularnya melalui seksual, transfusi darah ee jarum suntik bagi yang narkoba, ini saya dapatka karena gantianka itu jarum suntik do. pencegahannya supaya tidak menular, janganki baku pake-pake jarum, Pakai ki kondom saat berhubungan seksual biar nda tertular sama orang"(IT, 33 tahun, LTFU yang meninggal saat penelitian).

\section{EfekSampingPengobatanTerapiAntiretroviral}

Tiga informan yang berasal dari kelompok LTFU menyatakan bahwa efek samping yang sering dirasakan oleh ODHA saat menjalani terapi antiretroviral adalah pusing, mual, muntah, muncul ruam di kulit, gatal-gatal dan badan terasa lemas.Efek samping yang dirasakan cenderung mengganggu aktivitas sehari-hari.

"Gatal-gatalkakayak massissi-sissi (ada ruam) kulitku do,seringmual juga pusing..baru saya keluar masuk rumah sakit ji juga”. (AM ,45tahun, LTFU)

"Pertama dulu kuminum itu obat, ini kulit mukaku yang pertama ada flek, tapi lama kelamaan hilangmi, beberapa bulan kemudian terbiasami, nda adajilah efek yang berarti. Itu ji flek di kulit”. (IC,22tahun, LTFU)

"Iya oleng, ee pengen terus tidur dan lemas. Terganggu karena itu mi oleng, mual, lemas dan badanku kayak nda bisa bergerak. Jadi nanti bagus staminaku itu ketika jam-jam 1 atau 2 siang pi baru aktivitasku bagus, kalau pagi kayak drop saya rasa". (HS ,32 tahun, LTFU)

\section{DukunganKeluargadanPengawasMinumObat (PMO)}

Berdasarkan wawancara mendalam dengan tiga informan yang loss to follow up menyatakan bahwa selama menjalani terapi antiretroviral mereka mendapat dukungan dari petugas dan PMO berupa dukungan semangat dalam menjani terapi, rutin minum obat, jangan terlalu banyak pikiran, menjaga pola makan dan menghindari perilaku berisiko. Namun ada beberapa yang tidak mendapat dukungan dari keluarga karena mereka takut menceritakan kondisinya kepada keluarga, takut mendapatkan stigma, takut merasa diasingkan dan takut menambah beban pikiran keluarga akibat penyakit yang diderita.

Tetapi ada juga yang mendapatkan dukungan sepenuhnya dari keluarga walaupun awalnya semua pakaian dan segala milik anaknya dibakar, tapi setelah mendapatkan informasi tentang HIV dan AIDS dan memahaminya perlahan mereka menerima dan mendukung sepenuhnya terapi anggota keluarganya.

"Ada dari dokter dan PMO, Dukungan yang diberikan dalam bentuk semangat, jangan sampai putus obatnya, ee terus terapi, jangan lupa minum obatnya dan ee lebih utama jangan terlalu banyak pikir ee apa ee santailah, terus itu obat diutamakan”.(HS, 32 tahun, LTFU)

"Kalau dari keluarga kurang memberikan respon dan dukungan karena pada awal mereka tau saya kena penyakit ini, pakaian saya dibakar semua. Bahkan saya di usir, eloko manre pabbura, teako urusannu, eloko mate gatti alhamdulillah,, hehehe".(AT 33 tahun, LTFU yang meninggal).

"Keluarga saya nda ada yang tau kalau saya tertular penyakit ini sampai sekarang.Kalo dukungannya dokter sama teman PMO seperti kasih semangat, harus minum obat dengan teratur. Nakasi semangat ki..na kasi enjoylah pokoknya".(AM, 45 tahun, LTFU)

"Iye ada dari petugas dan PMO.Mamaku, saudaraku, mereka semua kasika Dukungan, supaya nda putus harapan, semuanya bikin saya semakin optimis, kurasa mereka kecewa kenapa saya putus obat, pasti mereka kecewa karna mereka banyak membantu, mengingatkan, cuma saya yang malas sebenarnya, saya sering lupa padahal mereka sering diingatkan". (MI, 22 tahun, LTFU)

"Iye bu maumi diapa, siapamami pale kalo bukan saya Dukungngi anakku, saudarana juga selalu suruh kedokter periksa. Bagaimana carana supaya tidak na putus asa anakku,supaya bisa kembali naminum obatna, batena tong itu kodong kuingatkan, cuma diaji yang malas sebenarnya, padahal sering diingatkan”. (IRT, 66 tahun, Keluarga HS)

"Iye bu iyako iya batena kasi kusuruh minum obat, tapi bapakna teani mitai rupanna, puralalo elo nawuno anakku kasi tapi biar bagaimana yako anak do bu...iya sedding elo mate, pekkogi carana supaya de na putus asa anakku,supaya bisa kembali naminum pabburana, batena tong itu kodong kusuruh, cuma alenamitu makuttu, padahal sering kuingatkan, waleng doi kasi”. (AS, 48 tahun, Keluarga MI)

\section{Akses Layanan}

Fasilitas kesehatan dengan fokus pada pemberian dukungan atas kebutuhan klien seperti perubahan perilaku untuk kepatuhan, dukungan mental, dukungan terapi ARV, pemahaman faktual dan terkini tentang HIV dan AIDS. Kegiatan konseling secara bertahap dapat mengikis stigma dan deskriminasi dikalangan penderita HIV dan AIDS. 
Pelayanan konseling dan test dilakukan secara sukarela oleh klien yang diduga terjangkit oleh virus HIV (AIDSINA, 2007).

"......sebenarnya kalau masalah akses, itu tidak ada masalah, teman-teman datang (ODHA) langsung kami layani,,,emm pernah memang obat ARV itu habis, mungkin disitumi mereka putus minum obatnya”.(IP, 30tahun, Petugas).

\section{Pembahasan}

\section{Pengetahuan}

Pengetahuan merupakan salah satu faktor predisposisi yang memengaruhi kepatuhan seseorang terhadap pengobatan yang dijalani.Sebagian besar pengetahuan diperoleh melalui mata dan telinga.Semakin tinggi pengetahuan seseorang tentang suatu hal maka perilakunya mengenai hal tersebut juga semakin baik.(Notoatmodjo, 2010).

Berdasarkan wawancara mendalam yang dilakukan kepada tiga informan yang LTFU, menunjukkan bahwa informan tidak memahami dengan jelas penyakit dideritanya. Mereka beranggapan bahwa HIV adalah penyakit yang berbahaya, mematikan dan tidak diketahui sampai kapan akan hilang. Informan tidak mampu memberikan penjelasan yang detail tentang penyakit HIV dan AIDS. Pengetahuan merupakan domain yang sangat penting untuk terbentuknya tindakan seseorang.

Penelitian Martoni et al. (2013) yang menunjukkan bahwa ODHA yang memiliki pengetahuan rendah memiliki risiko lebih tinggi untuk tidak patuh minum ARV. Tingkat pengetahuan yang memadai tentang penyakit HIV, pengobatan ARV meningkatkan kualitas hidup dan keyakinan bahwa kepatuhan yang buruk dapat menyebabkan resistensi virus dan kegagalan pengobatan semuanya akan berdampak baik pada pengobatan yang dijalani (Kwasa at al, 2004).

\section{Efek samping pengobatan}

Efek samping pengobatan ARV merupakan segala gejala yang timbul pada penggunaan obat antiretroviral (ARV) dapat berupa gejala simtomatik yang dapat dihilangkan dengan pemberian obat-obatan sampai pada gejala toksitas yang menyebabkan penggunaan obat harus dihentikan. Efek samping yang timbul dapat menurunkan kepatuhan penggunaan obat (Depkes RI, 2006).

Wawancara mendalam yang dilakukan kepada empat informan yang berasal dari kelompok LTFU menyatakan bahwa efek samping yang sering dirasakan oleh ODHA saat menjalani terapi antiretroviral adalah pusing, mual, muntah, muncul ruam di kulit, gatal-gatal dan sampai berhalusinasi. Keadaan ini yang menyebabkan mereka memutuskan pengobatan karena tidak sanggup menahan efek samping yang muncul.

Sejalan dengan peneitian Salema (2015) di Mzumbe menunujukkan bahwa sebanyak $3 \%$ ODHA loss to follow up terapi ARV karena takut terhadap efek samping terapi ARV. Dosis ARV mengandung kombinasi jumlah pil yang menyebabkan efek samping pada beberapa pasien seperti mual, ketidaknyamanan perut, muntah, diare dan ruam kulit akibatnya mayoritas pasien meninggalkan dosisnya dan berhenti menghadiri klinik seperti yang dijadwalkan. Efek samping yang lain adalah rasa lelah, dan sakit kepala yang disebabkan oleh azidotimidin (AZT) dan mimpi buruk akibat efavirenz. Beberapa efek samping yang lain yang jarang terjadi namun serius adalah anemia karena AZT, neuropati perifer akibat d4T (stavudine), toksisitas retinoid karena PI (Protase Inhibitor) dan reaksi hipersensitivitas akibat penggunaan NNRTI (Non-Nuleoside Reserve Transcriptase Inhibitor) (Ramadian and Riztriawan, 2010b).

Hasil penelitian ini juga memberikan informasi bahwa kejadian efek samping pengobatan ARV pada setiap ODHA bervariasi dan umumnya terjadi dalam tiga bulan pertama setelah inisiasi ARV. Berdasarkan wawancara mendalam dengan informan yang berasal dari dokter menyatakan bahwa efek samping yang dirasakan oleh ODHA selama menerima terapi antiretroviral wajar dirasakan, setiap orang beda-beda jangka waktunya, ada yang merasakan efek samping 1-2 minggu, ada yang 1 bulan, ada yang 6 bulan, bahkan ada pasien yang 1-2 tahun pengobatan masih merasakan efek sampingnya seperti pusing, sehingga pada saat konseling awal ODHA harus siap dengan berbagai macam efek samping yang akan muncul. Variasi kejadian efek samping inilah yang seringkali menyebabkan kejadian putus obat (loss to follow up) (Ramadian and Riztriawan, 2010a).

\section{Dukungan keluarga dan PMO}

Hasil penelitian memberikan inforrmasi bahwa empat informan yang loss to follow up (LTFU)selama menerima terapi antiretroviral mereka mendapat dukungan emosional, penghargaan dan informasional dari petugas dan PMO dalam bentuk semangat dalam menjalani pengobatan, motivasi untuk rutin minum obat, mengingatkan untuk tidak stress menjalani pengobatan, mengingatkan untuk menjaga pola makan dan menghindari perilaku berisiko serta diberikan informasi tentang penyakit HIV maupun pengobatan ARV yang dijalani.

Hasil penelitian ini juga memberikan informasi bahwa meskipun ODHA yang LTFU mendapat dukungan dari petugas dan PMO selama menjalani terapi ARV, namun mereka tidak mendapatkan dukungan dari pasangan 
maupun keluarganya, karena mereka takut akan adanya stigma dan diskriminasi. Sebagian besar informan mengungkapkan bahwa stigma dan diskriminasi masih dirasakan oleh ODHA. Hal ini yang menjadi hambatan bagi ODHA untuk mengungkapkan status mereka kepada pasangan dan keluarganya karena adanya ketakutan bagi ODHA akan penolakan dari pasangan dan keluarganya. Keluarga dan pasangan memilki peran penting dalam mendukung pasien ART, mengingatkan mereka untuk minum obat, meningkatkan rasa sosial kepada orang lain sehingga kepatuhan mereka terhadap pengobatan meningkat (Weaver et al., 2014).

\section{Akses layanan}

Fasilitas kesehatan dengan fokus pada pemberian dukungan atas kebutuhan klien seperti perubahan perilaku untuk kepatuhan, dukungan mental, dukungan terapi ARV, pemahaman faktual dan terkini tentang HIV dan AIDS. Kegiatan konseling secara bertahap dapat mengikis stigma dan deskriminasi dikalangan penderita HIV dan AIDS. Pelayanan konseling dan test dilakukan secara sukarela oleh klien yang diduga terjangkit oleh virus HIV (AIDSINA, 2007).

Layanan kesehatan di Rumah Sakit dapat merubah perilaku bersikap dalam beberapa kelompok rentan terhadap HIV di masyarakat (Mahardining, 2013).

Hasil penelitian menunjukkan bahwa ada hubungan antara faktor fasilitas pelayanan dengan loss to follow up pengobatan antiretroviral (ARV). Penelitian tersebut juga mengungkapkan bahwa pasien yang dapat dengan mudah mengakses kelayanan pengobatan ARV memiliki peluang 2 kali untuk patuh berobat ARV dibanding mereka yang sulit mengakses layanan pengobatan ARV.

\section{Kesimpulan}

1. Informan yang berasaldari ODHA LTFU memiliki Pemahaman yang minim diakibatkan informasi yang kurang mengenai HIV dan AIDS serta pengobatan antiretroviral, karena sebagian ODHA tidak menyerap dengan baik informasi yang diberikan oleh konselor, dokter maupun PMO.

2. Informan yang LTFU rata-rata kurang memilki kepercayaant erhadap pengobatan antiretroviral yang dijalani, karena mereka tidak merasakan manfaat dan tidak terbentuknya komitmen dalam diri ODHA untuk bersungguh-sungguh menjalani pengobatan seumur hidup.

3. Informan yang LTFU memutuskan pengobatan karena tidak sanggup menahan efek samping yang muncul. Selain efek samping yang dirasakan, sebagian ODHA memutuskan pengobatan karena timbulnya kejenuhan dalam mengkonsumsi obat ARV. Informan yang LTFU mendapatkan dukungan sosial yang sangat besar dari PMO dan tenaga kesehatan dalam bentuk dukungan emosional, penghargaan dan informasional, tetapi sangat minim mendapat dukungan dari keluarga karena takut akan adanya stigma dan diskriminasi

\section{Saran}

1. Memperkuat manajemen persediaan obat dalam mendukung pengadaan dan mencegah kehabisan stok persediaan obat di puskesmas.

2. Membuat program PMO untuk ODHA yang baru memulai terapi antiretroviral.

3. Bagi petugas diharapkan pada saat konseling awal memberikan informasi tentang (HIV, pengobatan ARV dan efek samping yang akan timbul selama menjalani pengobatan) sesuai dengan tingkat pendidikan dan factor risiko penularan ODHA, sehingga ODHA siapu ntuk menjalani pengobatan seumur hidup.

4. Petugas penanganan HIV dan AIDS agar lebih ramah terhadap ODHA bila mereka datang ketempat pelayanan, memberikan support dan sekaligus sebagai bentuk follow upterhadap pengobatan yang dijalani

\section{Referensi}

Hardiansyah, dkk 2014. Repository. unhas.ac.id (Diakses 28 Januari 2017)

Ditjen PP dan PL Kementerian Kesehatan RI, Statistik Kasus HIV dan AIDS di Indonesia, 2015

Kemenkes RI. 2014. Laporan Perkembangan HIV-AIDS Triwulan IV Tahun 2013. Jakarta : Kemenkes RI.

Kementerian Kesehatan Republik Indonesia. Pedoman Nasional Terapi Antiretroviral 2011. Departemen Kesehatan Republik Indonesia Direktorat Jendral Pengendalian Penyakit dan Penyehatan Lingkungan. Jakarta: 2011

Notoatmodjo, S., 2010. Promosi Kesehatan : Teori dan Aplikasi. Edisi Revisi 2010 Jakarta. Rineka Chipta.

Depkes RI. 2006. Situasi HIV/AIDS di Indonesia Tahun 1987-2006. Jakarta : Depkes RI. 
AIDSINA, 2007. Prosedur Layanan Konseling Tes HIV Sukarela dan Terapi ARV. Yayasan Citra Usadha Indonesia/ Ford Foundation: Indonesia

Mahardining, A.B., Hubungan antara Pengetahuan, Motivasi dan Dukungan Keluarga dan Kepatuhan Terapi ARV ODHA. Jurnal Kesehatan Masyarakat.

Fu. T, Westergaard, P. Ryan, B. Lau, Celentano, D. David, D. Vlahov, H. S. Mehta, DD. G. Kirk. 2012. Changes In Seksual and drug-Related risk behavior Following antiretroviral therapy initation among HIV-infected Injection drug use. AIDS (London, England), 26 (18), pp. 2383-91. Available at : hhtp://europepmc.org

Gerver, S.M., T.R. Chadborn, f. Ibrahim, B. Vasta, V.C. Delpech, P.J.Easterbrook. 2010. High rate of loss to clinical follow up among African HIV-infected patients attending a London clinic:a retrospective analysis of a clinical cohort. Journal of the InternationalAIDS Society, 13, p.29. Available From :

hhtp//www.pubmedcentral.nih.gov/articlerender.fcgi?artid=2924265\&tool=pmcentrez\&rendertype=abstract. 